\title{
Social networks and the spread of Lapita
}

\author{
Robin Torrence ${ }^{1} \&$ Pamela Swadling ${ }^{2}$
}

Lapita pottery seems to arrive in the Pacific out of the blue, and signal a new social, economic or ideological network. The authors show that widespread interaction, articulated by obsidian tools and stone mortars and pestles decorated with various motifs, was already in existence in New Guinea and New Britain. These earlier networks provide a preview of the social interaction that was to light up with the advent of Lapita.

Keywords: Bismarck Archipelago, Papua New Guinea, New Britain, Lapita pottery, networks, social interaction, obsidian, mortar and pestle

\section{Introduction}

Despite major research efforts, the spread of Lapita pottery within the Bismarck Archipelago of Papua New Guinea continues to be debated (Figure 1). Locally made pottery with ornate designs appeared $c .3300 \mathrm{cal} \mathrm{BP}-$ seemingly out of nowhere. With the possible exception of a plain ware assemblage from Mussau (Kirch 2001: 85), ceramics were not previously manufactured in this region and there are few if any local precursors for the elaborate dentate decoration that was eventually shared over an enormous region stretching from the Bismarck Archipelago, across Melanesia, and into western Polynesia (Kirch 1997; Spriggs 1997, but see Craig 1995). Pacific scholars are divided about whether the knowledge of pottery production and/or decoration was imported to the Bismarck Archipelago with immigrants or whether it represents a local adoption and adaptation of a new technology derived from Taiwan or the Philippines (e.g. Allen \& White 1989; Green 1991; 2000; Diamond \& Bellwood 2003: 601).

It has long been recognised that resolution of this debate requires comprehensive knowledge about prehistory during the time period directly before Lapita pottery (Allen 1989: 1). Unfortunately, most researchers have found that archaeological visibility during the mid-Holocene is poor, firstly, because rockshelters were largely abandoned; secondly, well-preserved coastal contexts dating prior to Lapita are rare due to taphonomic factors resulting from sea level change; and thirdly, because it is difficult to find open sites amidst the dense rainforest which covers nearly all northern Melanesia.

'Of noneconomic aspects of life among these mid-Holocene occupants of Near Oceania we as yet know almost nothing. . of their forms of kinship address and social organization, their mythologies and cosmologies. . The archaeological record is, for the present, mute, and I imagine

\footnotetext{
1 Anthropology, Australian Museum, Sydney, Australia (Email: robin.torrence@austmus.gov.au)

2 Department of Archaeology and Natural History, Research School of Pacific and Asian Studies, Australian National University, Australia (Email: pamela.swadling@anu.edu.au)
}

Received: 3 October 2007; Accepted: 27 November 2007; Revised: 8 January 2008

ANTIQUITY 82 (2008): 600-616 


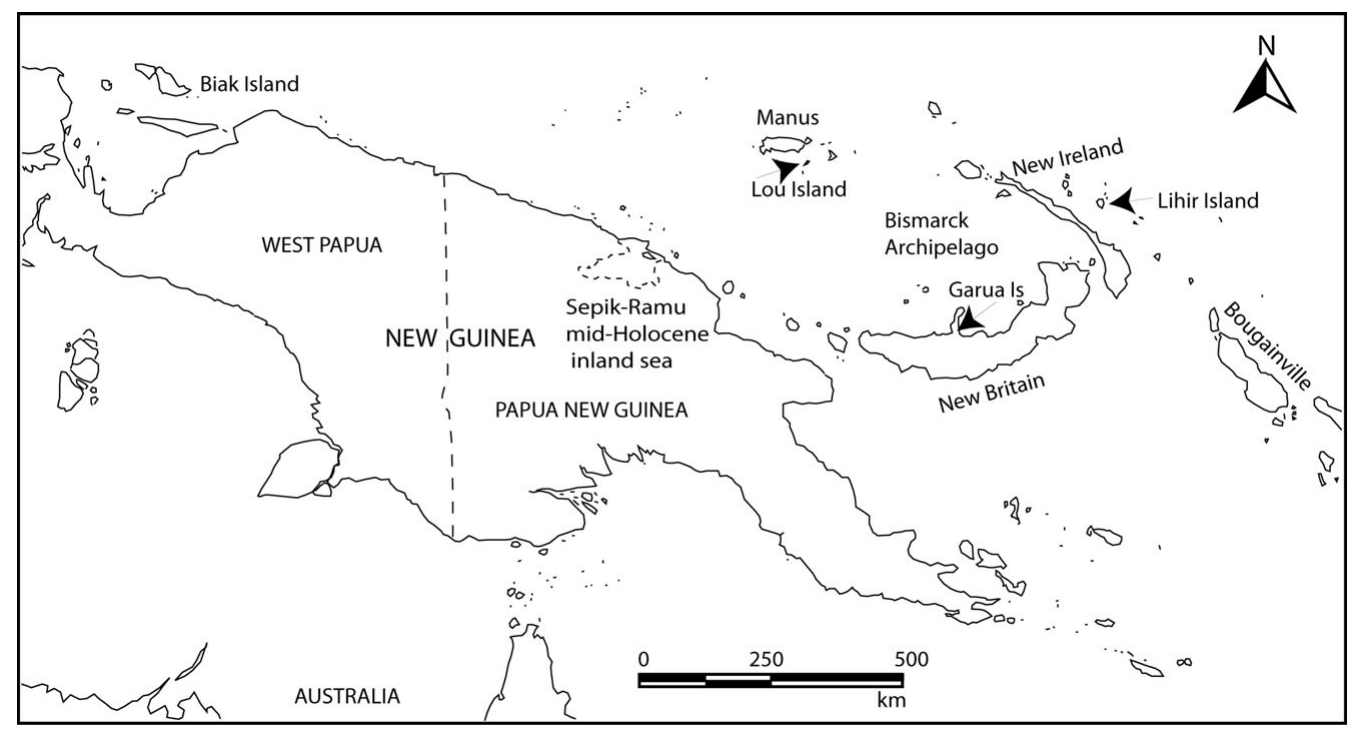

Figure 1. New Guinea showing the location of the Sepik-Ramu inland sea and surrounding islands.

that it will take the work of several more generations of archaeologists and historical anthropologists to even begin to draw back this veil of time' (Kirch 2000: 83).

Fortunately, it has not taken quite so long as Kirch predicted to find new ways to access mid-Holocene social systems and ideologies in Melanesia. This paper demonstrates the potential of two novel sources of data for drawing back Kirch's veil of time and sheds new light on the social antecedents of Lapita pottery in the Bismarck Archipelago. Scholars have previously suspected that the spatial distribution of stone mortars and pestles and stemmed obsidian artefacts represent social connections across large areas of Oceania (e.g. Riesenfeld 1950; Golson 1972; 2001), but without sound chronology, the provocative patterning was merely suggestive. We report recent research that dates these artefacts to the mid-Holocene and provides solid evidence for extensive long distance social networks. The identified interaction spheres raise the question whether Lapita pottery represents as revolutionary a change in cultural practices as has been previously suggested (e.g. Kirch 1997; 2000; Spriggs 1997) and also provide a possible mechanism for how it was spread throughout the Bismarck Archipelago.

\section{New approaches}

The first problem with studying poorly provenanced artefacts almost entirely from museum and private collections is dating. To find mid-Holocene archaeological contexts, survey and excavation must be extended out of the rockshelters and beyond the beaches, where almost all research efforts had been focused previously. Research in the inland regions of New Britain has capitalised on an excellent volcanic tephrochronology that provides relative dating for buried deposits across a large region (e.g. Torrence 2002; Pavlides 2006; Torrence \& Doelman 2007). A stratified series of volcanic tephras can be easily differentiated by macroscopic traits such as colour and texture as well as with geochemical analyses. These 

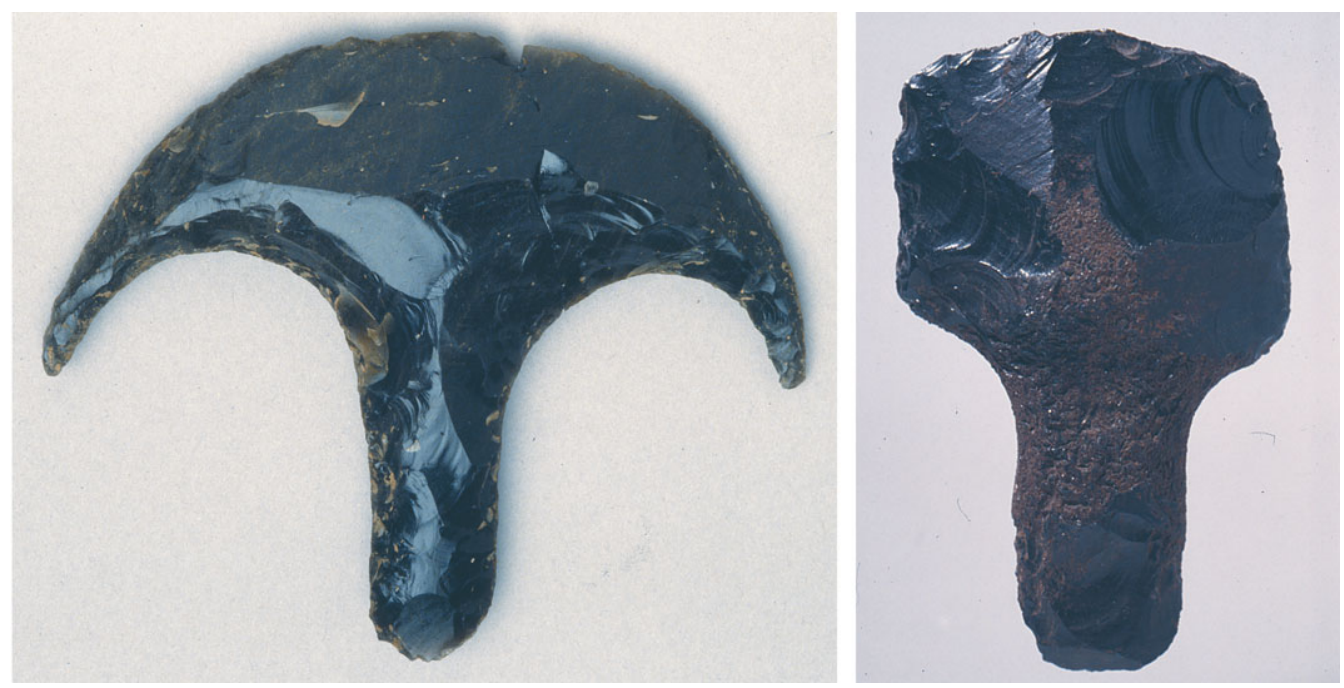

Figure 2. Large ceremonial obsidian stemmed tools. Left) Site FABN, New Britain (Torrence 2004a), length 107mm (photograph Paul Overden), National Museum and Art Gallery, Papua New Guinea. Right) Biak Island, (cf. Friede 2005: II, 86), length $132 \mathrm{~mm}$, Jolika collection, de Young Museum, San Francisco (photograph Robin Torrence).

are now well dated through radiocarbon analyses from material trapped within them and stratified in soil horizons between them (Torrence et al. 2000; Petrie \& Torrence in press).

The New Britain tephrastratigraphy has provided the first reliable dating for highly retouched obsidian tools previously only known from surface collections and as stray finds (Golson 1972). A number of scholars have proposed that the largest of these stemmed tools, as they are now known, probably functioned as ceremonial valuables (Araho et al. 2002; Torrence 2003; 2004a; Specht 2005) (Figure 2). In recent excavations stemmed tools have been recovered from deposits stratified underneath the W-K1 volcanic tephra. Only a very few examples occur above the W-K2 tephra which marks the beginning of Lapita pottery. Using the tephrochronology we can therefore trace the manufacture of these diagnostic artefacts as beginning some unknown time before 6160-5740 cal BP and ceasing by 3480$3160 \mathrm{cal} \mathrm{BP}$, perhaps due to the effects of the major natural disaster that resulted from the emplacement of the W-K2 tephra (Petrie \& Torrence in press).

New approaches have also been applied to stone mortars and pestles (Figure 3). Again recent research has enabled these artefact types to be soundly dated to the early and midHolocene. The chronology is based, first through association with particular environmental zones - as in the case of the distribution of mortars and pestles which surround the shores, but are not within the watery basin, of the Sepik-Ramu inland sea, which disappeared after $4000 \mathrm{cal}$ BP (Chappell 2005); secondly, through relative dating - they are not found in Lapita assemblages; and thirdly, stone mortars have been recovered from excavated contexts in New Guinea radiocarbon-dated between about 8000 and 3000 cal BP (Swadling 2004; 2005; Swadling \& Hide 2005).

Stemmed tools, mortars and pestles are excellent choices for monitoring social interaction during the mid-Holocene because stylistic similarities shared between widely spaced regions are unlikely to have arisen from independent invention. Like Lapita pottery, 


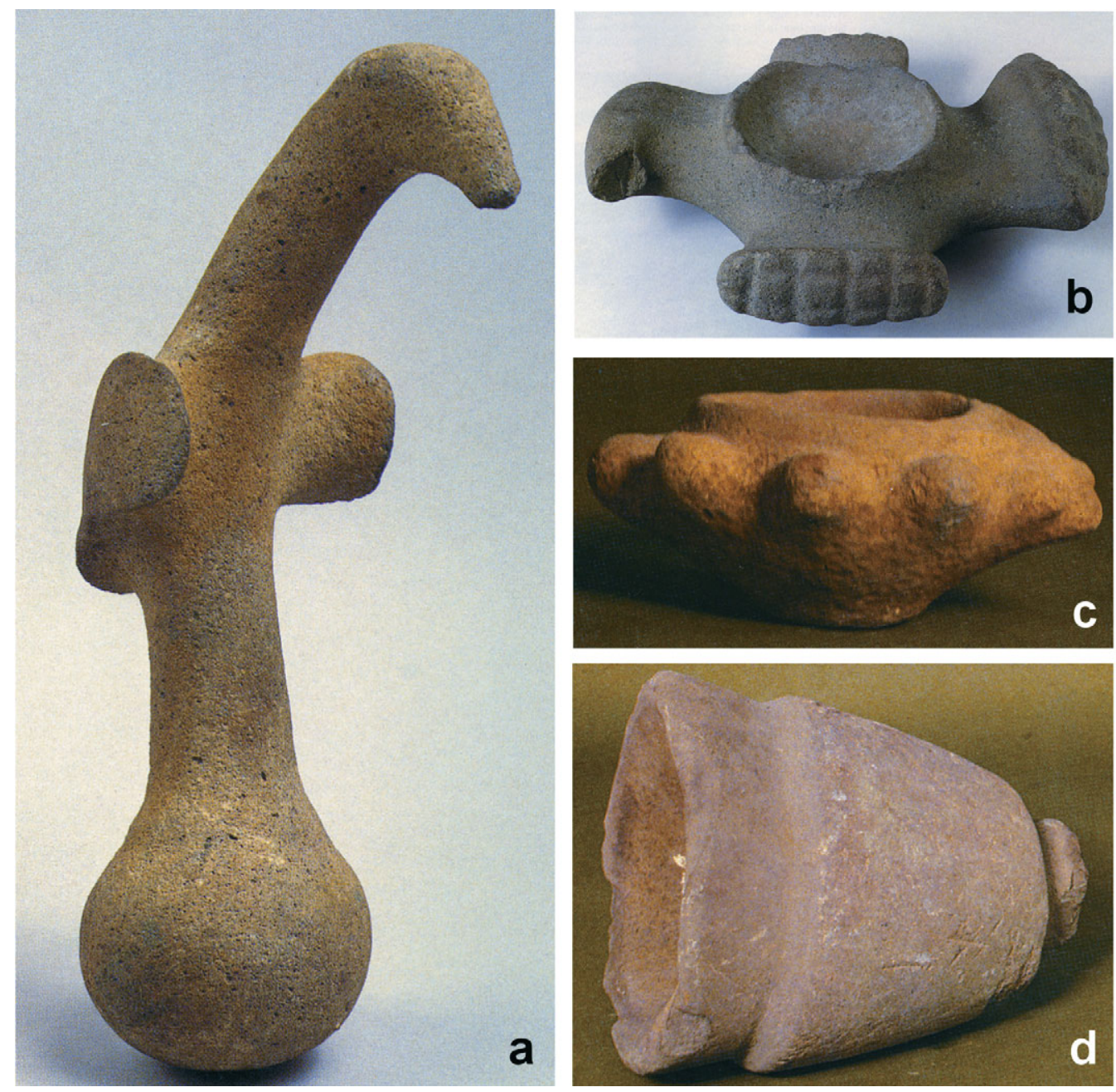

Figure 3. a) Pestle with bird motifs, height $280 \mathrm{~mm}$; b) mortar with bird head and wings, length 480mm; c) bossed mortar, height $227 \mathrm{~mm}$; d) footed mortar, length $335 \mathrm{~mm}$. a-b) Australian Museum (photographs Ric Bolzan); $c$-d) National Museum of Papua New Guinea (photographs Pou Tiovita).

these artefact types have distinctive decorations. In addition, the manufacture of both artefact groups required high inputs of time and energy, extensive knowledge, specialist skills, and appropriate raw materials, which in the case of obsidian was relatively rare. Furthermore, production by specialists offered opportunities for status enhancement both through restrictions over access to the final products and through the creation of links between makers and users. Large stemmed tools were designed to be fragile and are unlikely to have been utilitarian objects. Both artefact types were probably used in rituals and may have been exchanged as valuables (Araho et al. 2002; Torrence 2003; 2004a; Specht 2005). 


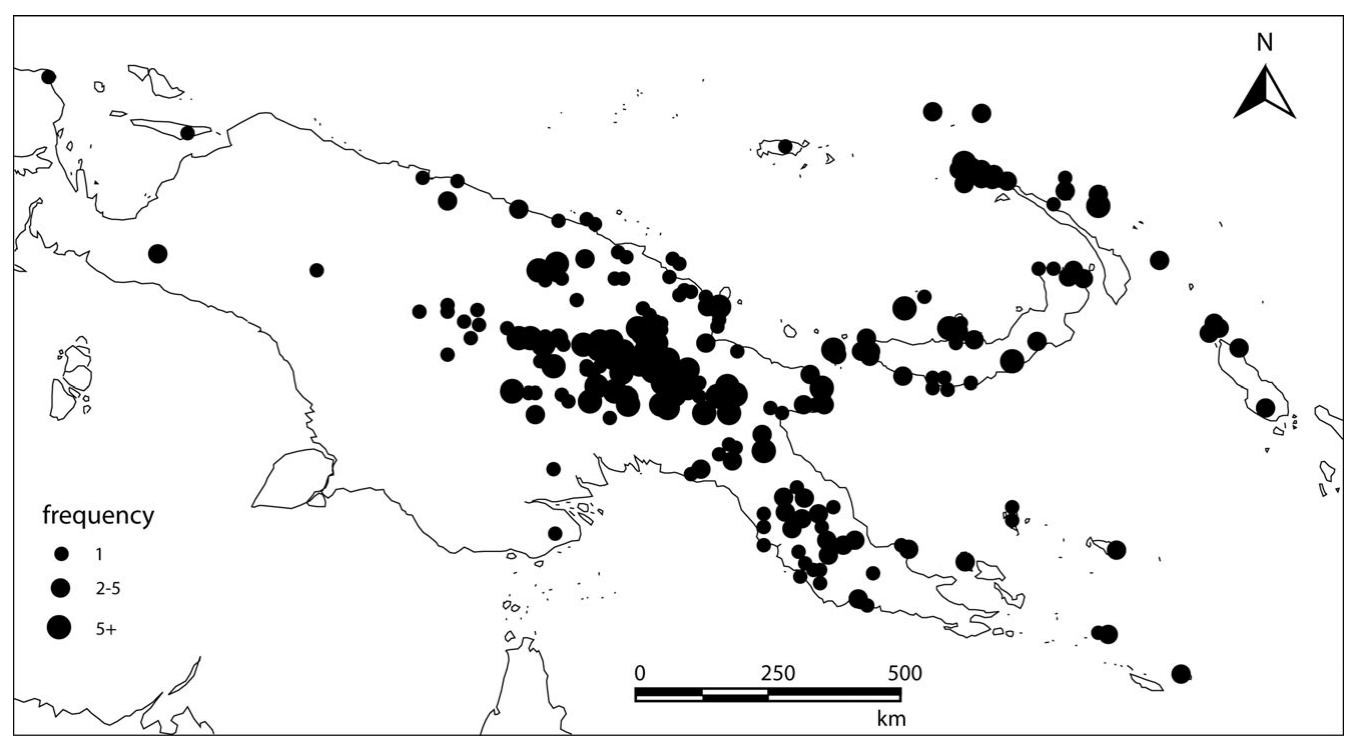

Figure 4. Distribution of stone mortars and pestles in Papua New Guinea and West Papua based on Swadling database. The major clusters in the New Guinea highlands and the widespread distribution in the islands are clearly visible at this large scale.

\section{Stone mortars and pestles}

Swadling's current database of $c .1000$ stone mortars and $c .750$ pestles, including published and unpublished artefacts in private and museum collections, provides the basis for distributional studies of stylistic variants of stone mortars and pestles. Stone mortars have an impressively large regional distribution stretching roughly from West Papua to at least Bougainville, with the greatest concentrations in mainland Papua New Guinea, New Britain and New Ireland (Figure 4). They occur in coastal and highland settings and are found on both the New Guinea mainland and surrounding islands, but they are restricted to lands suitable for the widespread growing of taro as a staple crop, but not those used primarily for yams, sago or bananas. Swadling has therefore suggested that they may have been used in gardening magic and other rituals which involve the making of taro puddings (Swadling 2004; Swadling \& Hide 2005). The wide-scale manufacture of these artefacts, made from various types of hard stone, suggests that many different cultural groups shared notions about their functions and meanings.

Swadling has argued that the sharing of particular styles of mortars and pestles among widely spaced cultural groups is the consequence of social interaction (Swadling 2005; Swadling \& Hide 2005; Swadling et al. in press). To illustrate how common and widespread cultural links were during the mid-Holocene, four interaction spheres defined largely by shared decorative styles on mortars and pestles are presented in Figure 5. These represent just a sample of the potential axes of social interchange that will be revealed when the database has been analysed further.

The most extensively researched interaction sphere to date operated within New Guinea, between the shores of the Sepik-Ramu inland sea (which according to Chappell (2005) 


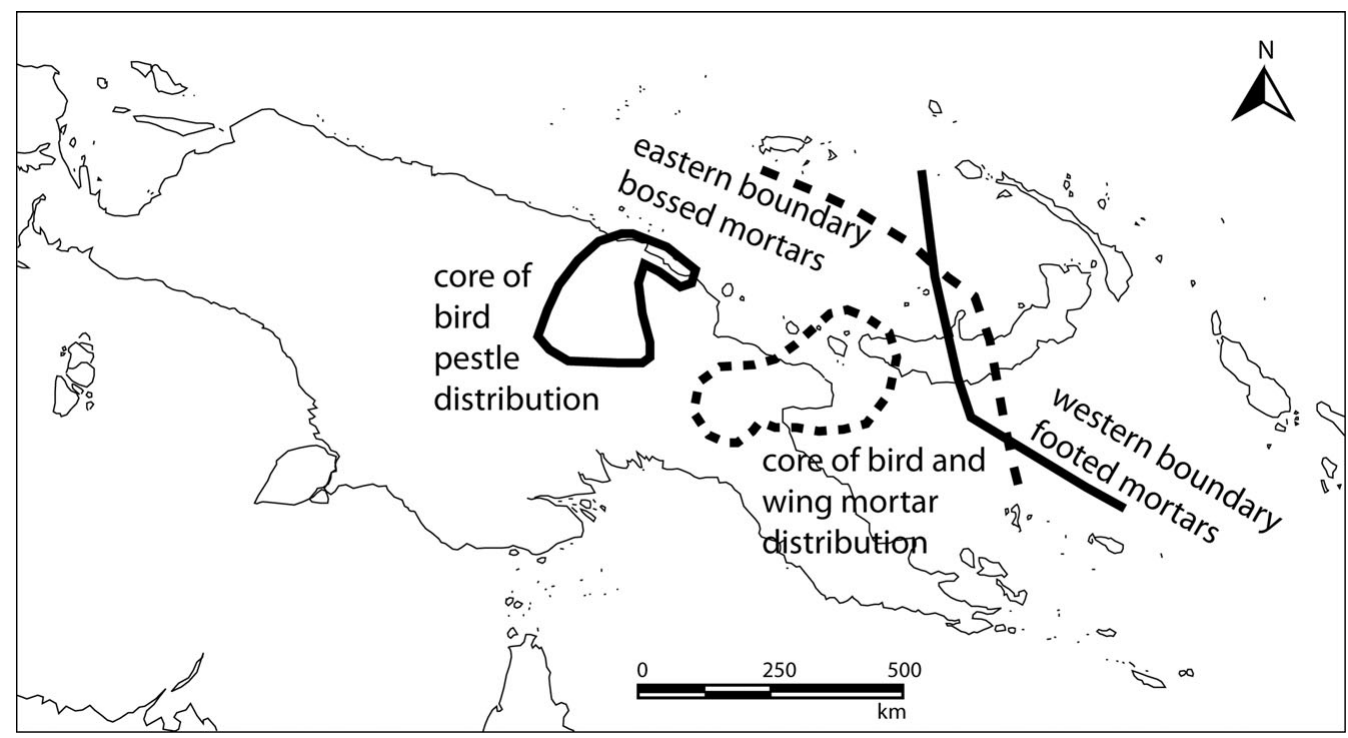

Figure 5. Interaction zones defined by distinctive styles of mortars and pestles.

reached its greatest extent $c$. 6500-7500 cal BP and had infilled by $4000 \mathrm{cal} \mathrm{BP}$ (Figure 1)) and the Central Highlands (Swadling \& Hide 2005). It was probably associated with the exchange of products from different environmental zones, including valuable bird of paradise plumes (Swadling 1996). The most characteristic items found in this zone are pestles with bird motifs, particularly wings but also beaks (Figures 3 and 6). Outside this interaction sphere, groups were linked over a wider area but through different mechanisms. For example, several examples of bird pestles occur outside the Sepik-Ramu/highlands sphere in eastern and southern New Guinea in locations situated along well-known recent trade routes. Further, local copies of bird pestles are recorded from New Britain and possibly New Ireland (Figure 6), indicating that some items, concepts and perhaps associated ceremonies moved outside the core area, probably through other kinds of social contexts.

Mortars with bird wings and in some cases also with bird heads are the most diagnostic feature of the second zone of interaction (Figures 3 and 7). This region stretches from the western tip of New Britain, through the Huon Gulf to the Kainantu area of the Eastern Highlands.

The third case probably encompasses a number of interaction spheres. It is defined by mortars bearing distinctive bosses (Figures 3 and 8). The boundaries have not yet been clearly delimited. This interaction zone is spread across both highland and lowland eastern New Guinea and extends as far east as the Willaumez Peninsula in New Britain where there is a clear boundary. To the west, bossed mortars have not been found in West Papua. Although further study may divide it into smaller subzones, it seems likely that the large variety of bossed mortars in the region represents a more diffuse network of social relations than mortars and pestles with bird motifs.

Finally, the fourth case consists of an island-centred sphere of interaction defined by footed mortars, which appear in a wide range of forms (Figures 3 and 9). They have been 


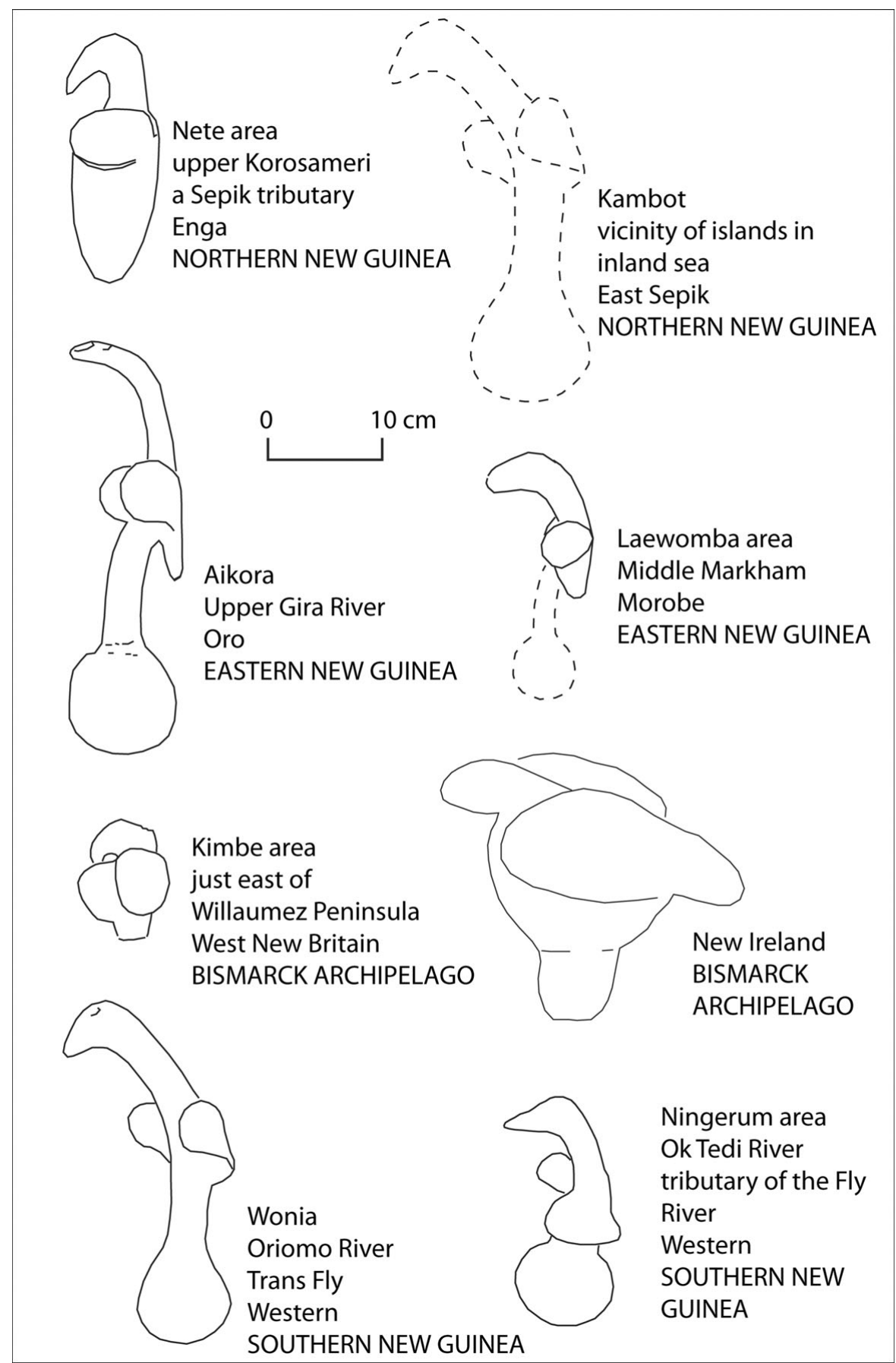

Figure 6. Pestles with bird motifs. 


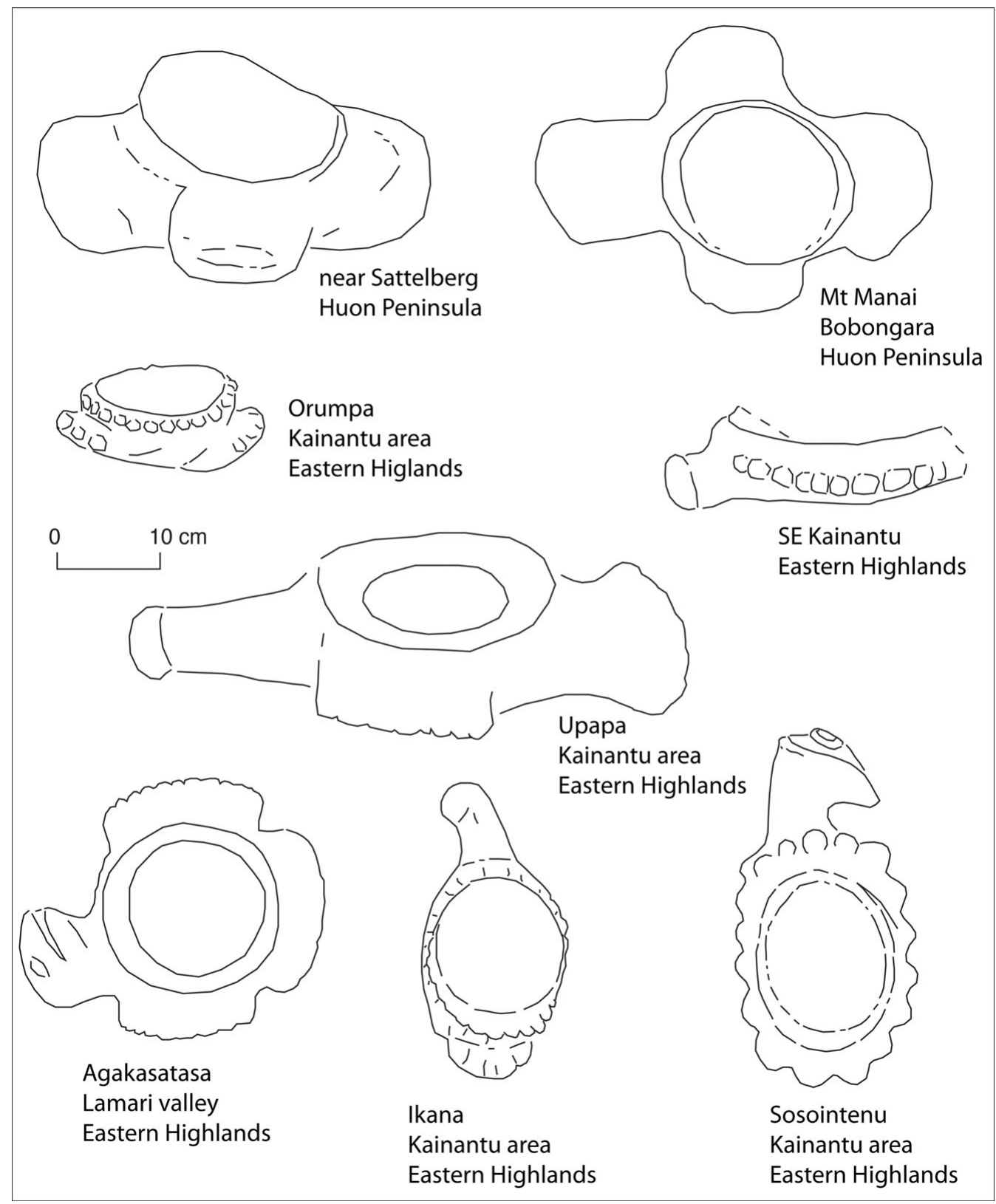

Figure 7. Mortars with bird motifs.

found in New Ireland and New Britain and there is a clear western border at the Willaumez Peninsula.

Stylistic analyses of mortars and pestles show that people copied and recreated concepts in much the same way as locally-made Lapita pottery was later decorated with shared designs. The mortar and pestle style zones are the product of social interaction among groups 


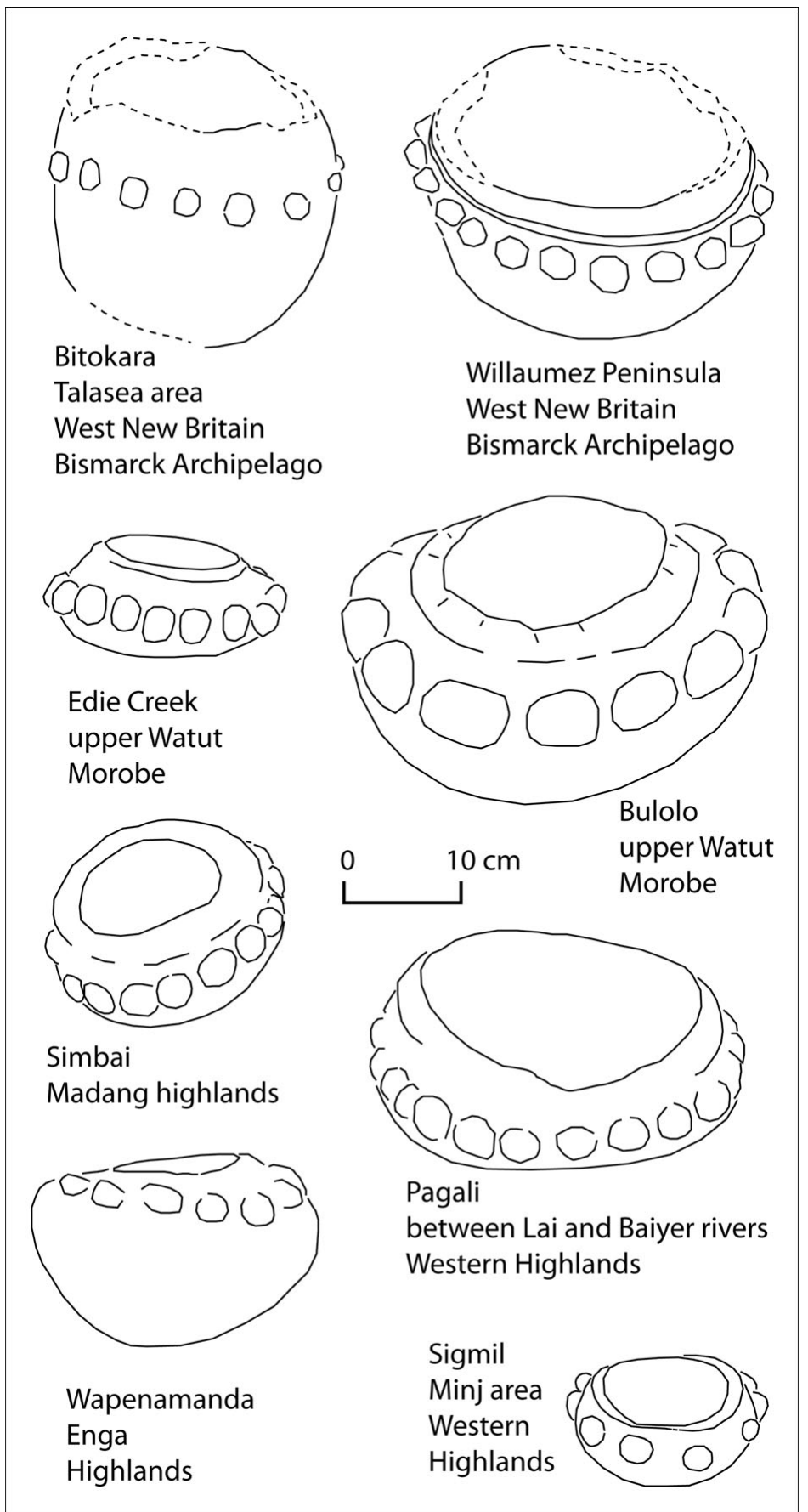

Figure 8. Bossed mortars. 


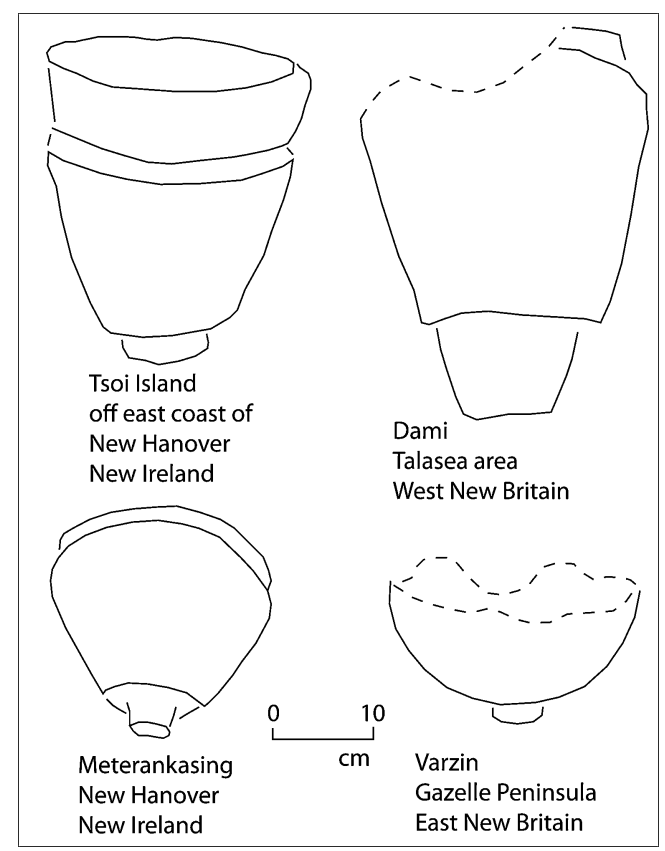

Figure 9. Footed mortars. who used the same design concepts, probably as a consequence of sharing and exchanging valuables, ceremonies, dances, songs, etc. The spatial pattern of these four interaction spheres demonstrates the existence of a complex set of cross-cutting social networks within the New Guinea highlands and which created links to the islands of the Bismarck Archipelago during the mid-Holocene. Although the styles and the practices underlying them may have been passed among neighbouring groups, significant travel and maritime contact is required for the widespread distribution of bossed and footed mortars. Furthermore, even if all the styles were not contemporary, this preliminary summary of patterns teased out of the extensive database shows that at any one time there were probably enough overlapping interaction zones to have facilitated the spread of ideas and

practices from the highlands of New Guinea to Bougainville, a distance of over $1000 \mathrm{~km}$.

\section{Obsidian stemmed tools}

At this early stage in identifying stone pestle and mortar style zones, the Willaumez Peninsula in New Britain stands out as a 'hub' of social interaction because the eastern end of mainland bossed mortars overlaps with the western boundary of the island footed mortars (Figure 5). Significantly, this region is also the source area for obsidian that was transported widely throughout Melanesia, including during the time of Lapita pottery (e.g. Summerhayes et al. 1998). However, due to the paucity of archaeological contexts, the mid-Holocene transport of obsidian has only been well studied for New Britain. The results of an extensive characterisation study in New Britain showed that at any one locality obsidian artefacts were derived from several sources, indicating that multiple sets of social links were forged with people resident in a number of different places (Torrence 2004b).

The best evidence for spatially extensive social networks that circulated obsidian is the spatial distribution of casual finds of stemmed tools held in private and museum collections (Golson 1972; Specht 2005; Torrence et al. in press). Like the mortars and pestles, the astoundingly large spread of stemmed tools (Figure 10) must be the product of social interaction that operated across a vast area, stretching from Biak Island in the west to Bougainville in the east (a distance of $c .2200 \mathrm{~km}$ ) (Figure 1) and overlapped with mortar 


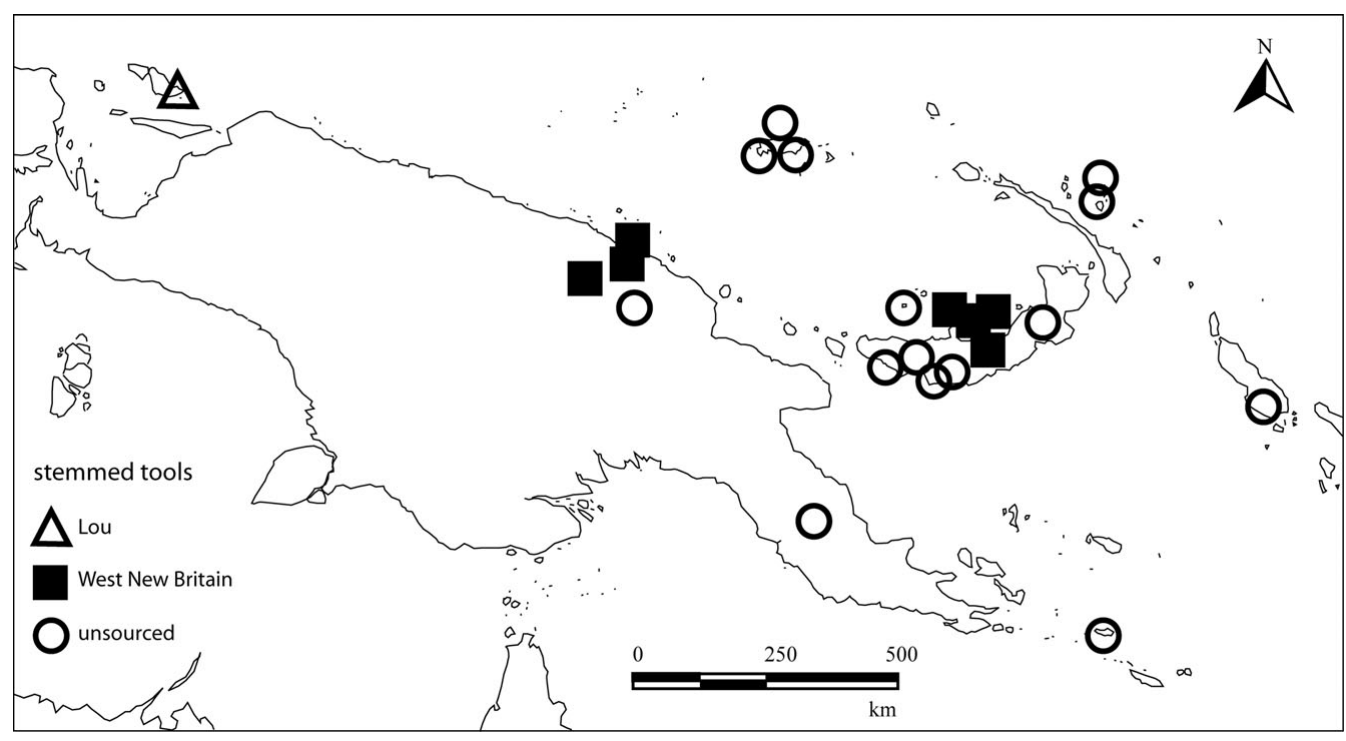

Figure 10. Spatial distribution of obsidian stemmed tools. The different symbols represent the geological source. Multiple numbers of tools have been sourced for each of the localities shown in West New Britain (cf. Araho et al. 2002; Rath \& Torrence 2003). See Figure 1 for location of Lou Island.

and pestle interaction spheres on the mainland, particularly in the Sepik region, and the Willaumez Peninsula (cf. Figure 5).

The distribution of stemmed tools differs from that of stone mortars and pestles and Lapita pottery because they were probably made only at the few restricted localities where there are obsidian outcrops (Araho et al. 2002), so the actual objects were moved rather than the knowledge of how and what to manufacture and decorate. For this reason stemmed tools may have circulated through different kinds of social networks than those represented by shared styles among the mortars and pestles. One might argue that the widely distributed stemmed tools were simply rare leakages from societies living close to the obsidian sources in New Britain and therefore not the consequence of significant social interaction. New results from geochemical studies negate this hypothesis and verify strong social connections.

Previously, stemmed tools from New Britain and the Sepik region were characterised to the New Britain source areas of Kutau/Bao, Baki, Gulu in the Willaumez Peninsula and Mopir in the Hoskins Peninsula, all of which preserve abundant evidence for local production (Araho et al. 2002; Rath \& Torrence 2003; Swadling \& Hide 2005). Surprisingly, a new study using both laser ablation ICPMS and PIXE PIGME has sourced the most distant stemmed tool, from Biak Island (Friede 2005: II, 86; Figures 2 and 11) to the Umleang obsidian source on Lou Island, in Manus province (Figure 11) and represents the first evidence that this source was in use during the mid-Holocene (Torrence et al. in press).

The Biak Island artefact is remarkably similar to stemmed tools found on Garua Island, just offshore from New Britain, but, surprisingly, it was made instead from obsidian that 


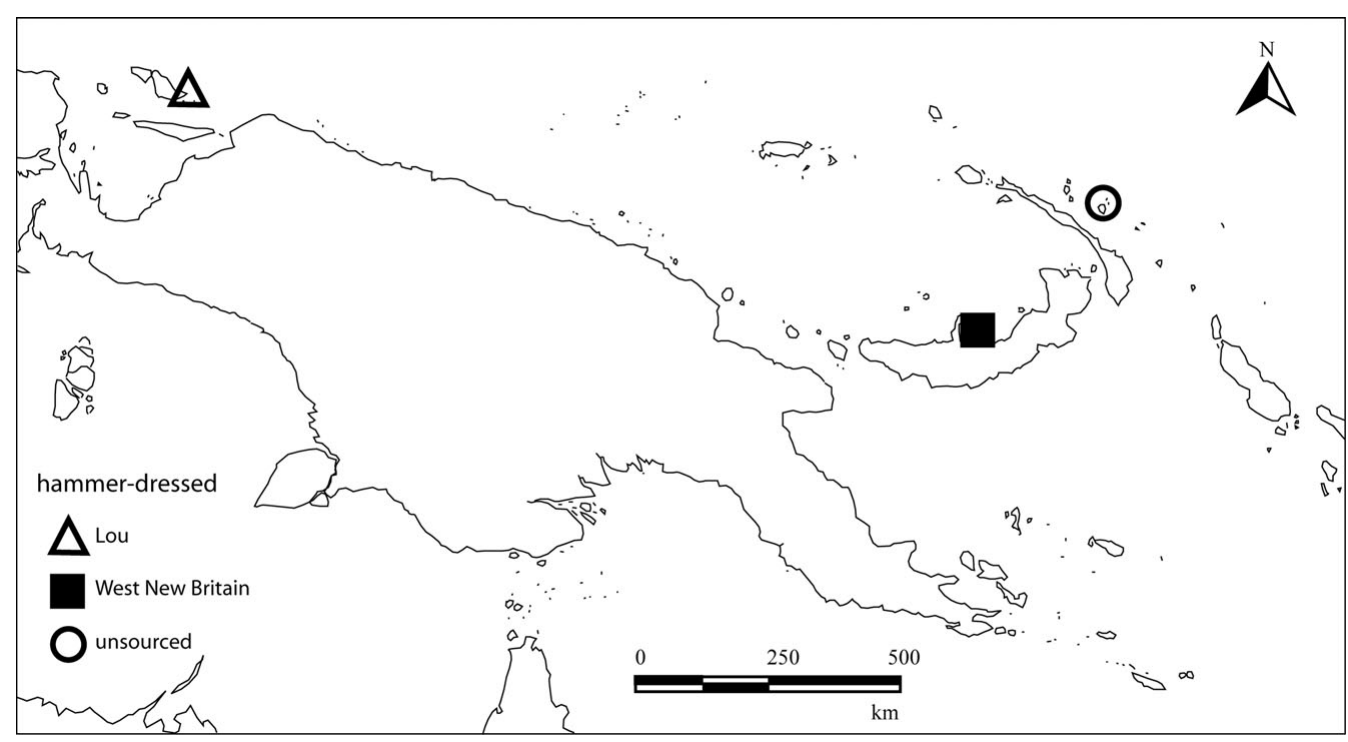

Figure 11. Spatial distribution of hammer-dressed obsidian artefacts. The different symbols represent the geological source. See Figure 1 for location of Lou Island.

outcrops on Lou Island (Figures 1 and 11). Many of the New Britain stemmed tools, like the Biak tool, were made with a specialised manufacturing sequence involving the creation of a kombewa flake, which is derived from a blow across the bulbar surface of a large flake used as the core (Araho et al. 2002). From experimental replication, we know that this procedure is complex, requires considerable knowledge and skills unlikely to have been shared widely, and demands large cobbles of raw material, which are relatively scarce (Kim Akerman \& Nina Kononenko pers. comm.). Furthermore, the Biak tool has been hammer-dressed, a technique unknown for obsidian elsewhere in the world, except for six obsidian stemmed tools from Garua Island made from the Baki and Kutau/Bao New Britain sources and one unsourced artefact from Lihir in New Ireland (Figure 11). Although hammer-dressing may have been applied to improve the grip of the handle or assist with hafting, applying a forceful technique like pecking to a fragile tool and removing obsidian's trademark, and often meaningful, shininess suggests attempts to enhance the value of the tool through specialist labour and/or particular symbolic meanings (Torrence 2005; Torrence et al. in press).

The Biak stemmed tool might have been manufactured on Lou Island using the identical rare and difficult techniques used on Garua Island. It has definitely not been reworked from a blade like those from the late prehistoric periods on Manus (Fredericksen 2000). In contrast, it was made on a kombewa flake struck from a flake core and therefore lacks the dorsal arris of a blade. Torrence et al. (in press) have also discussed at length why it is unlikely that the artefact was moved from Manus to Biak Island in recent years. Stemmed tools have been found nearby on Manus Island (Araho et al. 2002: 72) (Figure 10), although they have not been sourced. 
A second possibility is that raw material was taken from Lou to Garua where a specialist knapper converted it into a stemmed tool. The elaborate production sequence could certainly have formed the centrepiece of a ceremony in which social relations between maker and consumer were forged or the status of the artefact owner was enhanced (see Rath \& Torrence 2003; Carter 2007). Although unlikely, there is a precedent: obsidian from the Kutau/Bao source on mainland New Britain was transported to the Baki outcrops on offshore Garua Island where it was manufactured into stemmed tools (Rath \& Torrence 2003). Further research on Lou Island is required to investigate whether stemmed tools were made there, but this will be difficult since the mid-Holocene landscape is deeply buried under volcanic tephra (Ambrose et al. 1981).

Plausible explanations for the remarkable similarity among stemmed tools made from the two widely separated obsidian sources must account for a significant sharing of concepts, values, and knowledge. The production sequence is far too difficult, complex, and, in the case of hammer-dressing, possibly counter-intuitive, for independent invention. Alternately, the high investment of time and effort required to copy the technology indicates that stemmed tools were at least as highly valued by the borrowers as by the original consumers and implies the artefacts may have circulated within a single social interaction sphere. However the similarity was achieved, it is reasonable to assume that the distribution of obsidian stemmed tools signals social interaction between widely spaced Lou and Garua islands and possibly also across the entire distribution of obsidian stemmed tools.

\section{Interaction spheres}

We propose that the mortar and pestles style zones and the spatial distribution of obsidian stemmed tools are the consequences of extensive social networks in New Guinea and the Bismarck Archipelago during the mid-Holocene, c. 8000-3300 cal BP. In the first instance, the large-scale circulation of stemmed tools originally quarried from relatively small geological outcrops of obsidian in New Britain or Lou Island suggests these objects were valuables within a system of competitive exchange, perhaps operating along similar lines to many recent Melanesian societies (Araho et al. 2002; Torrence 2004a). The presence of ceremonial valuables enables us to propose social differentiation among individuals or groups within mid-Holocene societies along the lines that Kirch (1988; 2000: 1125) and others (see review in Spriggs 1997: 102) have previously inferred for societies contemporary with Lapita pottery on the basis of shell valuables. Consequently, we can push back the beginnings of a fundamental aspect of Oceanic societies beyond the time of Lapita pottery.

Since the mid-Holocene social networks had been circulating ideas and materials over a very large area, probably for several thousand years, they were well placed to have played a critical role in the seemingly sudden appearance of Lapita pottery throughout the Bismarck Archipelago. It is therefore relevant to question whether the social interchange responsible for the spread of Lapita pottery-making and decoration was significantly different from its mid-Holocene antecedents. We envisage the context in which styles of mortar and pestle 
decorations were shared and transferred as similar to recent social settings in which new ceremonies including songs, dances, costumes, and other decorations (e.g. bilas in Papua New Guinea Tok Pisin) are eagerly sought after from trade partners. As a result, both intangible and material items can be transferred across a region, such as from the Sepik coast inland into the Prince Alexander Mountains (Mead 1970). Lapita pottery might well have been a ceremonial accessory that travelled through established social networks and was replicated locally along with popular songs, dances, masks, etc. in the same way that mortar and pestles styles had been shared previously.

At the time that Lapita designs appeared, the mid-Holocene networks were probably undergoing change firstly, due to the rapidly prograding shoreline and advancing SepikRamu floodplain (Chappell 2005), which cut off direct ties between the New Guinea highlands and the coast and, secondly, as a consequence of the Witori W-K2 volcanic eruption in New Britain that must have seriously disrupted social groups in that region (e.g. Torrence \& Doelman 2007). The resulting realignment of social networks at this time may have provided an opportunity for the successful introduction of behaviour and ideas from outside the local region.

\section{Conclusions}

Research into the mid-Holocene antecedents of Lapita pottery in the Bismarck Archipelago is needed to demystify the widespread distribution of this distinctive ceramic series. Although archaeological deposits dating just prior to Lapita pottery have been difficult to locate, we have shown that significant information previously hidden away in museum and private collections creates a new picture about mid-Holocene social processes relevant to debates about the spread of Lapita. It also seems likely that the nature of the decorations on these objects (e.g. bird motifs) informs us about cosmology, despite Kirch's (2000: 83) pessimism noted previously. Although analyses of recently dated artefacts, such as stone mortars and pestles and obsidian stemmed tools, have only just begun to scratch the surface of what can be learned from distributional studies, they paint a new picture of social processes and exchange during the mid-Holocene.

The mapping of different styles of stone mortars and pestles and the spatial distribution of obsidian stemmed tools reveal multiple overlapping interaction spheres as well as more diffuse social networks that operated within and between New Guinea and the surrounding islands during the mid-Holocene. The widespread distribution of these shared artefact types and styles of decoration raise questions about whether and in what ways the appearance of Lapita pottery signals a radical increase in the complexity of social organisation. Although additional research is required to clarify the nature of the social processes responsible for these interaction spheres, clearly ideas and objects were distributed across large distances before Lapita pottery appeared. The circulation of valuables implies a degree of social differentiation that previously has only been associated with later pottery-using communities (e.g. Friedman 1981; Hayden 1983; Kirch 1997: 254; Spriggs 1997: 102), but which must have developed much earlier. In addition, the desire for new ceremonies and associated material culture among mid-Holocene communities could have created the contexts in which the practice 
of decorating pottery with Lapita designs was adopted as well as the initial conduits for its rapid spread. New ideas, rituals, and technologies, whether developed locally or introduced from outside, could have travelled quickly through established networks across an enormous region stretching from at least Biak Island all the way to Bougainville.

\section{Acknowledgements}

We thank AINSE, Australian Research Council, Australian Museum, Australia and Pacific Foundation, Earthwatch Institution, New Britain Palm Oil, Ltd. for funding; John Friede, National Research Institute (PNG), National Museum and Art Gallery (PNG), University of Papua New Guinea, West New Britain Provincial Cultural Centre, Walindi Plantation, and Kimbe Bay Shipping Agencies for support; Wal Ambrose and Glenn Summerhayes for help with obsidian sourcing, project members, fieldwork volunteers and local communities in West New Britain.

\section{References}

Allen, J. 1989. Introduction, in J. Allen \& C. Gosden (ed.) Report of the Lapita Homeland Project (Occasional Papers in Prehistory 20): 1-8. Canberra: Department of Prehistory, Research School of Pacific Studies, Australian National University.

Allen, J. \& J.P. White. 1989. The Lapita homeland: some new data and interpretations. Journal of the Polynesian Society 98: 129-46.

Ambrose, W., J. Bird \& P. Duerden. 1981. The impermanence of obsidian sources in Melanesia, in F. Leach \& J. Davidson (ed.) Archaeological studies of Pacific stone resources (British Archaeological Reports International Series 104): 1-19. Oxford: British Archaeological Reports.

Araho, N., R. Torrence \& J.P. White. 2002. Valuable and useful: mid-Holocene stemmed obsidian artifacts from West New Britain, Papua New Guinea. Proceedings of the Prehistoric Society 68: 61-81.

CARTER, T. 2007. The theatrics of technology: consuming obsidian in the early Cycladic burial arena. Anthropological Papers of the American Anthropological Association 17: 88-107.

Craig, B. 1995. Arrow designs in Northern and Central New Guinea and the Lapita connection, in D. Smidt, P. Keurs \& A. Trouwborst (ed.) Pacific material culture: essays in honour of Dr Simon Kooijman: 237-59. Leiden: Rijksmuseum voor Volkenkunde.

Chappell, J. 2005. Geographic changes of coastal lowlands in the Papuan past, in A. Pawley, R. Attenborough, J. Golson \& R. Hide (ed.) Papuan pasts: cultural, linguistic and biological histories of Papuan-speaking peoples: 289-328. Canberra: Pacific Linguistics.

Diamond, J. \& P. Bellwood. 2003. Farmers and their languages: the first expansions. Science 300: 597-603.
Fredericksen, C. 2000. Points of discussion: obsidian blade technology in the Admiralty Islands, $2100 \mathrm{BP}$ to 50 BP. Bulletin of the Indo-Pacific Prehistory Association 20: 93-106.

Friede, J. 2005. New Guinea art masterpieces from the Jolika collection of Marcia and John Friede. San Francisco (CA): Fine Arts Museum of San Francisco.

Friedman, J. 1981. Notes on structure and history in Oceania. Folk 23: 275-95.

Golson, J. 1972. Both sides of the Wallace Line: New Guinea, Australia, Island Melanesia and Asian prehistory, in N. Barnard (ed.) Early Chinese art and its possible influence in the Pacific Basin: 533-96. New York: Intercultural Arts Press.

- 2001. New Guinea, Australia and the Sahul connection, in A. Anderson, I. Lilley \& S. O'Connor (ed.) Histories of old ages: essays in honour of Rhys Jones: 85-210. Canberra: Pandanus Books.

Green, R. 1991. The Lapita cultural complex: current evidence and proposed models. Bulletin of the Indo-Pacific Prehistory Association 11: 295-305.

- 2000. Lapita and the cultural model for intrusion, integration and innovation, in A. Anderson \& T. Murray (ed.) Australian archaeologist: collected papers in honour of Jim Allen: 372-93. Canberra: Coombs Academic Publishing.

Hayden, B. 1998. Social characteristics of early Austronesian colonizers. Indo-Pacific Prehistory Association Bulletin 4: 123-34.

KIrCH, P. 1988. Long-distance exchange and island colonization: the Lapita case. Norwegian Archaeological Review 21: 103-17.

- 1997. The Lapita peoples. Oxford: Blackwell.

-2000. On the Road of the Winds: an archaeological history of the Pacific Islands before European contact. Berkeley (CA): University of California Press. 


\section{Robin Torrence \& Pamela Swadling}

- 2001. A radiocarbon chronology for the Mussau Islands, in P.V. Kirch (ed.) Lapita and its transformations in Near Oceania: archaeological investigations in the Mussau Islands, Papua New Guinea, 1985-88 (Contributions of the University of California Archaeological Research Facility 59):196-222. Berkeley (CA): Archaeological Research Facility, University of California.

Mead, M. 1970. The Mountain Arapesh II: arts and supernaturalism. New York: American Museum of Natural History.

Pavlides, C. 2006. Life before Lapita: new developments in Melanesia's long-term history, in I. Lilley (ed.) Archaeology of Oceania: Australia and the Pacific Islands: 205-27. Oxford: Blackwell.

Petrie, C. \& R. Torrence. In press. Assessing the effects of volcanic disasters on human settlement in the Willaumez Peninsula, Papua New Guinea: a Bayesian approach. Holocene 19(5).

Riesenfeld, A. 1950. The Megalithic culture of Melanesia. Leiden: Brill.

Rath, P. \& R. Torrence. 2003. Producing value: stemmed tools from Garua Island, Papua New Guinea. Australian Archaeology 57: 119-27.

Specht, J. 2005. Obsidian stemmed tools in New Britain: aspects of their role and value in mid-Holocene Papua New Guinea, in I. Macfarlane, R. Paton \& M. Mountain (ed.) Many exchanges: archaeology, history, community and the work of Isabel McBryde (Aboriginal History Monograph 11): 357-72. Canberra: Australian National University.

Spriggs, M. 1997. The Island Melanesians. Oxford: Blackwell.

Summerhayes, G.R., J.R. Bird, R. Fullagar, C. Gosden, J. Specht \& R. Torrence. 1998. Application of PIXE-PIGME to archaeological analysis of changing patterns of obsidian use in West New Britain, Papua New Guinea, in S. Shackley (ed.) Archaeological obsidian studies: 129-58. New York: Plenum.

Swadling, P. 1996. Plumes from Paradise: trade cycles in outer Southeast Asia and their impact on New Guinea and nearby islands until 1920. Cooparoo, Australia: National Museum of Papua New Guinea in association with Robert Brown \& Associates.

- 2004. Stone mortar and pestle distribution in New Britain revisited, in V. Attenbrow \& R. Fullagar (ed.) A Pacific Odyssey: archaeology and anthropology in the Western Pacific. Papers in honour of Jim Specht (Records of the Australian Museum Supplement 29): 157-62. Sydney: Australian Museum.
- 2005. The Huon Gulf and its hinterlands: a long-term view of coastal-highlands interactions, in C. Gross, H. Lyons \& D. Counts (ed.) A polymath anthropologist: essays in honour of Ann Chowning (Research in Anthropology and Linguistics Monograph 6): 1-14. Auckland: University of Auckland.

Swadling, P. \& R. Hide 2005. Changing landscape and social interaction: looking at agricultural history from a Sepik-Ramu perspective, in A. Pawley, R. Attenborough, J. Golson \& R. Hide (ed.) Papuan pasts: cultural, linguistic and biological histories of Papuan-speaking peoples: 289-328. Canberra: Pacific Linguistics.

Swadling, P., P. Wiessner \& A. Tumu. In press. Prehistoric stone artifacts from Enga and the implications of links between the highlands, lowlands and islands for early agriculture in Papua New Guinea. Journal de la Société des Océanistes.

Torrence, R. 2002. Cultural landscapes on Garua Island, Papua New Guinea. Antiquity 76: 766-76.

- 2003. 'Like everywhere you've never been': archaeological fables from Papua New Guinea, in R.J. Jeske \& D.K. Charles (ed.) Theory, method and practice in modern archaeology: 287-300. Westport (CT): Praeger.

- 2004a. Pre-Lapita valuables in Island Melanesia, in V. Attenbrow \& R. Fullagar (ed.) A Pacific Odyssey: archaeology and anthropology in the Western Pacific. Papers in honour of Jim Specht (Records of the Australian Museum Supplement 29): 163-72. Sydney: Australian Museum.

- 2004b. Now you see it, now you don't: changing obsidian source use in the Willaumez Peninsula, Papua New Guinea, in J. Cherry, C. Scarre \& S. Shennan (ed.) Explaining social change: studies in honour of Colin Renfrew: 115-25. Cambridge: McDonald Institute for Archaeological Research.

- 2005. Valued stone: how so?, in I. Macfarlane, R. Paton \& M. Mountain (ed.) Many exchanges: archaeology, history, community and the work of Isabel McBryde (Aboriginal History Monograph 11): 357-72. Canberra: Australian National University.

Torrence, R. \& T. Doelman. 2007. Problems of scale: evaluating the effects of volcanic disasters on cultural change in the Willaumez Peninsula, Papua New Guinea, in J. Grattan \& R. Torrence (ed.) Living under the shadow: cultural impacts of volcanic eruptions: 42-66. Walnut Creek (CA): Left Coast Press. 
Torrence, R., C. Pavlides, P. Jackson \& J. Webb. 2000. Volcanic disasters and cultural discontinuities in the Holocene of West New Britain, Papua New Guinea, in B. McGuire, D. Griffiths \& I. Stewart (ed.) Archaeology of geological catastrophes: 225-44. London: Geological Society of London.
Torrence, R., P. Swadling, N. Kononenko, W. Ambrose, P. Rath \& M. Glascock. In press. Mid-Holocene social interaction in Melanesia: new evidence from hammer-dressed obsidian stemmed tools. Asian Perspectives. 